\title{
Discrimination against Foreigners: The Wuerttemberg Patent Law in Administrative Practice
}

\section{Sibylle Lehmann-Hasemeyer and Jochen Streb}

In the second half of the nineteenth century, the patent office of the German state Wuerttemberg strategically discriminated against foreign inventors by charging comparatively high patent fees. We show that this administrative practice was driven by fiscal and protectionist motives.

ince the Agreement on Trade-Related Aspects of Intellectual Property
Rights (TRIPS) was added to World Trade Organization (WTO) law in 1994, some economists have called into question whether it makes sense to push developing countries to introduce strict patent laws (Grossman and Lai 2004; Peukert 2017; Auriol, Biancini, and Paillacar 2019). The main argument is that intellectual property rights primarily foster exporters from industrial countries by hampering product piracy. Companies from developing countries, on the other hand, are more likely to suffer from the introduction of a strict patent law because the enforcement of foreigners' intellectual property rights keeps them from catching up by learning through imitation.

In the nineteenth century, the German state of Wuerttemberg, which is today one of the most innovative and prosperous European regions, ${ }^{1}$

The Journal of Economic History, Vol. 80, No. 4 (December 2020). (C) The Economic History Association. All rights reserved. doi: 10.1017/S0022050720000479. This is an Open Access article, distributed under the terms of the Creative Commons Attribution licence (http://creativecommons.org/licenses/by/4.0/), which permits unrestricted re-use, distribution, and reproduction in any medium, provided the original work is properly cited.

Sibylle Lehmann-Hasemeyer is Professor, University of Hohenheim, Wollgrasweg 49, Stuttgart 70599, Germany. E-mail: sibylle.lehmann@uni-hohenheim.de. Jochen Streb is Professor, Department of Economics, University of Mannheim, L 7, 3-5, Mannheim 68131, Germany. E-mail: streb@uni-mannheim.de.

This project was partly funded by the German Science Foundation (DFG) as part of the Priority Program 1859 "Experience and Expectation. Historical Foundations of Economic Behaviour." We are very grateful for the comments of Carsten Burhop, Alexander Donges, Louis Pahlow, Felix Selgert, and the participants of the workshop "Patent Law and Innovation in Europe during the Industrial Revolution" in Bonn in February 2018, the annual meeting of the Wirtschaftshistorischer Ausschuss of the Verein für Socialpolitik in Frankfurt in March 2018, the European Social Science History Conference in Belfast in April 2018, the World Economic History Conference in Boston in August 2018, and the Third Congress of Economic and Social History in Regensburg in March 2019. The usual disclaimer applies.

${ }^{1}$ Greater Stuttgart (NUTS-2 level) is actually ranked $14^{\text {th }}$ among the 20 European regions with a gross domestic product per capita that is 50 percent or more above the European Union average. See Eurostat news release 52/2017. For the outstanding concentration of world-market leaders in Wuerttemberg, see Streb (2019, p. 18). 
was in a very similar situation as today's developing countries. Being one of the founding members of the German Customs Union (Zollverein), Wuerttemberg had agreed not to discriminate against inventors from other member states in 1842. Thus, Wuerttemberg's companies seemed to be at the mercy of the competition of technologically advanced firms from states, such as Prussia or Saxony, and there was a fear that this competition would hinder the state's own economic development substantially. As the administrative practice of Wuerttemberg demonstrates, however, a government's lip service to the principle of equal treatment does not guarantee that the local patent authority really refrains from discriminating against foreign patentees. We show that Wuerttemberg decided to break codified rules to which the other member states presumably adhered and discriminated against foreign inventors by charging comparatively high patent fees that led them to waive their patent protection prematurely. To identify the fundamental causes of this patent policy, we distinguish between strategic economic policy considerations, that is, fiscal and protectionist motives, and non-economic influences such as nationalism or xenophobia. ${ }^{2}$ We provide empirical evidence that the patent office of Wuerttemberg strategically put at a disadvantage those foreign inventors who lived in the most innovative countries or patented innovation that particularly affected the industries that dominated Wuerttemberg's economy at this time. It is outside the scope of this article to evaluate whether the Wuerttemberg strategy of discriminating against foreign patent holders was successful and accelerated the pace of economic development in the state. This would require either a full-fledged counterfactual analysis with many restrictive assumptions or a cross-German state panel regression with an extensive set of control variables, which is not possible at the current state of data availability. ${ }^{3}$

\section{THE HISTORY OF PATENT DISCRIMINATION}

Following Douglass C. North's path-breaking contribution, economists (North and Weingast 1989; North 1990; DeLong and Shleifer 1993; Acemoglu, Johnson, and Robinson 2001) interpret the establishment of

\footnotetext{
${ }^{2}$ This approach was inspired by Timmer and Williamson (1998) who analyzed market and nonmarket influences of the changes in American immigration policy during the globalization backlash.

${ }^{3}$ For an overview of the German patent legislation before 1877, see Donges and Selgert (2019b). In another research project, these authors use a new hand-collected patent data set, including all patents that were granted in the German states between 1843 and 1877, to determine how those states' different patent laws affected innovation activity before the harmonization of the German patent law in 1877 (see Donges and Selgert 2019c).
} 
inclusive institutions that guarantee free market access, secure property rights, and reduce transaction costs as a necessary precondition for sustained economic growth. To prove the causal nexus between the quality of institutions and economic performance for the German industrialization, Acemoglu et al. (2011) analyze the long-term impact of the Napoleon-led French occupation of states in Northwestern and Western Germany that came along with radical institutional change such as the abolition of guilds and serfdom or the introduction of a civil legal code. The authors conclude that the longer a German state was under French rule, the more firmly the new inclusive institutions became anchored in German society and the higher, therefore, was subsequent economic growth. Based on these findings, Donges, Meier, and Silva (2018) try to identify the channel through which the institutional reform influenced economic development the most. Using data about the distribution of valuable patents across German regions after 1877 (Streb, Baten, and Yin 2006), they observe that German counties with the longest period of French occupation had more than twice as many valuable patents per capita than unoccupied German counties that stuck to their traditional institutions for some additional time. That is why Donges, Meier, and Silva (2018) claim that inclusive institutions are a first-order determinant of innovation and, therefore, growth.

Most scholars who emphasize the positive effects of the codification of inclusive institutions implicitly assume that the administration will enforce them effectively. This is not something to be taken for granted. On the one hand, bureaucrats might be unwilling to implement the new rules because they still cling to the old ways of misusing their discretionary power for their personal benefit. Selgert (2018) discusses for the case of the German state Baden, which had also been under French occupation, how the Grand Duke of Baden established an efficient and uncorrupt administration in the decade after Napoleon's defeat. On the other hand, bureaucrats might not be allowed to enforce the new rules because their superiors have ordered them to follow instructions that are opposed to the official law. A case in point is the principal of national treatment, which can be found in every modern patent law, that many patent authorities have disobeyed in the past.

To give local firms the opportunity to imitate foreign innovations at low cost, less developed countries have always been tempted to discriminate against foreign inventors from more advanced countries. Antebellum America provides a classic example for a country that openly favored domestic inventors (Khan 2005, p. 57). Initially, the U.S. Patent Statute of 1793 had limited the right to acquire a U.S. patent to American citizens 
alone. In the following decades, this discriminatory provision was relaxed to the extent that foreigners with permanent American residence became entitled to apply for U.S. patents too. The Patent Act of 1836 finally opened the American patent system to foreign inventors living outside the United States; however, they had to pay a significantly higher patent fee than domestic inventors. Hard hit above all were the British inventors, who had to give $\$ 500$ for an American patent, while for all other nationalities, a fee of $\$ 300$ was enough. ${ }^{4}$ To make it comparatively expensive for British inventors to hold an American patent was not without economic logic. Since Great Britain was the technologically most advanced country of the early nineteenth century, American firms could profit the most from selling unprotected British innovations in their large home market.

To what extent a domestic manufacturer profited from patent discrimination against foreigners depended largely upon the volume of its export activities, because any additional profit a firm could get from preferential treatment at home could potentially be offset by a decrease in export gains that resulted from foreign retaliatory measures (Geng and Saggi 2015, p. 15). That is why open patent discrimination against foreigners became a less attractive policy measure during the second half of the nineteenth century, when globalization led to strongly increasing international trade flows (O'Rourke and Williamson 1999). In an international attempt to end the era of patent discrimination, the founding members Belgium, Brazil, France, Guatemala, Italy, the Netherlands, Portugal, Salvador, Serbia, Spain, and Switzerland established the Paris Convention for the Protection of Industrial Property in March 1883. The United Kingdom joined this agreement in 1884, the Unites States of America in 1887, and Germany in 1903 (Seckelmann 2006, pp. 226-28). ${ }^{5}$ The most important outcome of the Paris Convention was the principle of national treatment, which required that each national patent law treated domestic and foreign patent applicants equally. ${ }^{6}$ This rule has been retained until today. Notably, article 3 of TRIPS from April 1994 confirms the Paris

\footnotetext{
${ }^{4}$ American applicants had to pay a fee of only $\$ 30$.

${ }^{5}$ Status April 2018, 177 states have joined the Paris Convention for the Protection of Industrial Property.

${ }^{6}$ The original Paris Convention was written in French. Article 2 reads: "Les sujets ou citoyens de chacun des États contractants jouiront, dans tous les autres États de l'Union, en ce qui concerne les brevets d'invention, les dessins ou modèles industriels, les marques de fabrique ou de commerce et le nom commercial, des advantages que les lois repectives accordant actuellement ou accorderont par la suite aux nationaux. En consequence, ils auront la même protection que ceux-ci et le même recours legal contre toute atteinte portée à leurs droits, sous reserve de l'accomplissement de formalités et des conditions imposes au nationaux par la legislation intérieure de chaque État." The World Intellectual Property Organization (WIPO) provides the original version of the Paris Convention in the historical archives of its homepage.
} 


\section{Wuerttemberg Patent Law in Administrative Practice 1075}

Convention and obliges all member states of the WTO to comply with the principle of national treatment. ${ }^{7}$

This milestone on the way to a global patent law, however, also marks the growing resistance against a too early involvement of the developing countries whose technological inferiority might get cemented by a strict patent law (for a review, see Maskus 2008). The criticism intensified at the beginning of the twenty-first century when international pharmaceutical companies took action against South Africa's attempt to ensure the provision of affordable AIDS/HIV medicine through national legislation. Even though the pressure on South Africa was dropped, discussion about the impact of patent law on economic and social development has not ceased since then.

Arguably, national governments decided to give up discriminating against foreigners and to join the Paris Convention because they assumed that their domestic industries would realize net gains from enjoying secure intellectual property rights in their various export markets. Even better than a world where everybody adheres to the principle of national treatment, however, is a world where everybody except oneself is doing so. Because written law could no longer comprise any formal discriminatory clauses, discrimination against foreigners had to manifest itself now in informal administrative or juridical procedures that outsiders could not easily observe (or prove). Webster, Jensen, and Palangkaraya (2014) argue that patent examiners' task to evaluate the inventiveness or nonobviousness of a patent application gives them the leeway in decisionmaking to prefer domestic inventors. Analyzing the examination practice of European and Japanese patent offices between 1990 and 1995, they find that domestic inventors are more likely to get a patent grant than foreign ones. Mai and Stoyanow (2014) assume that judges favor domestic firms in patent litigations. Based on information about the outcomes of all intellectual property rights litigations that took place in Canada between 2007 and 2010, they calculate that foreign firms face a smaller probability of winning the case. Another way to discriminate against foreigners is to delay their patent grants to give domestic inventors the time to gain a competitive edge by filing many improvements around the original foreign patent application (Kotabe 1992). Richter and Streb (2011) demonstrate that the German patent authority obviously used this strategy to support the domestic machine tool industry in the 1920s when the review period for American filers took more than twice as long as for German ones.

This was not the first case of discriminating against foreigners in the history of German patent administration. We will show in the following

\footnotetext{
${ }^{7}$ https://www.wto.org/english/docs_e/legal_e/27-trips-03_e.htm, accessed on 15 June 2018.
} 
that the patent authority of the Kingdom of Wuerttemberg chose in the nineteenth century a less subtle way to prefer local patentees by imposing significantly higher patent fees to foreign inventors. We will argue that this administrative practice was not easily observable and gave the patent authority, therefore, the freedom of action to discourage foreign inventors from seeking long-term patent protection in Wuerttemberg. To prove this claim, we will first elaborate the patent law of Wuerttemberg and discuss the possible reasons why a foreign patentee had to pay higher patent fees than a local one. In the second step, we will provide statistical evidence to prove the hypothesis that Wuerttemberg's patent office strategically discriminated against foreigners for fiscal and protectionist reasons.

\section{THE PATENT LAW OF WUERTTEMBERG AND DETERMINANTS OF THE PATENT FEE}

Before 1877, no nationwide patent law existed in Germany. Instead, the larger German states had established their own state-specific patent laws that differed considerably with respect to the examination procedure and the patent fees demanded (Donges and Selgert 2019b). The Prussian patent law, which is often referred to as exemplary for the German innovation system of the nineteenth century as a whole, was in fact rather the exception. Even if the very low patent fees give the impression that the Prussian legislator designed the patent system in a way that provided for many the opportunity to get patent protection, Prussian examination practice was rather restrictive. The Prussian patent inspectors rejected up to 90 percent of the patent applications judging them not to meet the requirement of novelty and inventive ingenuity. While the Prussian patent law mirrored many characteristics of the American patent law, most German middle states, such as Bavaria or Saxony, decided to follow the British example and established only a weak examination procedure. As a result, patents per capita were much higher in these states than in Prussia. In the 1860 s, for example, Saxony and Bavaria granted annually 70 and 20 patents per one million inhabitants, respectively, whereas the Prussian number came only to 3.6 (Donges and Selgert 2019b).

Using the Bavarian patent legislation of 1825 as a model (Gehm 2001, p. 87; Seckelmann 2006, pp. 100-4), Wuerttemberg introduced its own patent rules within the trade act of $1828 .^{8}$ The legislature especially

\footnotetext{
${ }^{8}$ See Allgemeine Gewerbe-Ordnung vom 5. Mai 1828, in Regierungs-Blatt für das Königreich Württemberg vom Jahr 1828, pp. 237-86. The patent rules can be found under Articles 143-163. The revised trade act of 1836 confirmed the patent legislation of 1828. See Articles 141-160 of the Revidierte allgemeine Gewerbe-Ordnung vom 5. August 1836, in Regierungsblatt für das Königreich Württemberg 1836, pp. 385-434.
} 
copied the weak Bavarian examination procedure. That is why the patent authority of Wuerttemberg refused only about 10 percent of all patent applications (Vischer 1875, p. 498), which is in stark contrast to the Prussia rejection rate of 90 percent. Notwithstanding the basic similarity with the Bavarian patent law, the patent system of Wuerttemberg also possessed some rather unique features that allowed for discriminating against foreigners. First, privileged access to information about inventions of third parties was provided for locals. In contrast to current practices, under the patent law of Wuerttemberg, a patentee was generally not obliged to publish the description of his ${ }^{9}$ patent during its life span. Residents of Wuerttemberg, however, had the right to see the patent description in the last year before a patent finally expired..$^{10}$ This privilege gave the locals a head start when it came to imitating an innovation whose patent protection was lapsing.

Another special feature of the patent law of Wuerttemberg was that the same patent fee did not apply to all patents. Instead, the patent authority was free to assign to each patent an individual fee that could range between 5 and 20 South German guilders (fl) per year. ${ }^{11}$ In the 1850 s, an artisan from Wuerttemberg earned a daily wage, on average, of about 150 pfennigs; 240 pfennigs corresponded to one guilder. ${ }^{12}$ Thus, a local artisan had to work about 11 days to cover the annual fee of about seven guilders, which people from Wuerttemberg had to pay, on average. Foreign inventors regularly faced a much higher nominal patent fee than the residents of Wuerttemberg did. We will show that even inventors who resided within the borders of the Zollverein (but not in Wuerttemberg) had to pay a patent fee that was three-quarters higher than the average patent fee of a resident from Wuerttemberg. ${ }^{13}$

It can be argued that the members of the patent authority expressed their personal aversion of certain foreign countries by setting particularly high patent fees for their inhabitants. In this case, Wuerttemberg's patent policy would have been determined by xenophobia and a certain degree of arbitrariness. We consider the alternative that the patent

\footnotetext{
${ }^{9}$ The use of the possessive pronoun "his" indicates that, in the nineteenth century, male inventors held the vast majority of patents. See Khan (2017).

${ }^{10}$ See Article 150 of the trade act of 1828 .

${ }^{11}$ See Article 151 of the trade act of 1828 . In most of our cases, the patent authority fixed the annual patent fee at 5, 10, 15, or 20 guilders. Patent fees of 6 and 12 guilders appear in a few cases.

${ }^{12}$ See Statistisches Landesamt für Baden-Württemberg (1974), p. 20.

13 The German Zollverein was founded in 1834 (Keller and Shiue 2014; Ploeckl 2015). Prussia, Hesse-Darmstadt, Kur Hesse, Bavaria, Wuerttemberg, and Saxony were the founding members. Baden and Hesse Nassau joined in 1835, Frankfurt/Main in 1836, Brunswick in 1841, Luxembourg in 1842, and Hanover and Oldenburg in 1854. Hamburg, Bremen, and Lübeck as well as Holstein, Mecklenburg, and Schleswig remained outside in our period of observation.
} 
authority pursued strategic economic objectives when discriminating against foreigners. We, therefore, start our discussion of determinants by looking at how the patent administration itself explained the differences in the allocated patent fees. In a self-report, published in 1875, the patent authority of Wuerttemberg claimed to have been guided by two major principles when fixing patent fees in the last 25 years (Vischer 1875, p. 495).

The first principle was based on a fiscal motive. Between 1849 and 1873 , the state of Wuerttemberg took a sum total of 60,000 South German guilders from patent fees (Vischer 1875, p. 498), which corresponded to an annual average of about 0.2 percent of total government revenue in this period (Mauersberg 1988, p. 171). To foster state revenues, the patent authority stated to have followed the rule to increase the patent fee with the expected profit an inventor would gain from his patent. ${ }^{14}$ But how could the patent administration assess the profitability of an individual patent? One possibility was to rely on available information about the innovative strength of an inventor's home country. Following Moser (2005, 2012), we assume that contemporary World's Fairs provided such information. The more exhibits a country presented at one of the prominent World's Fairs of the time, the more innovative it might have been in the eyes of the Wuerttemberg patent administration. A second way to evaluate a patent's profitability was to take the geographical distance of an inventor's residence into account. With the help of an empirical gravity model, Wolf (2009) has shown that nineteenth-century German states predominantly traded with their geographical neighbors. That is why inventors from neighboring countries probably expected an above-average trade volume with Wuerttemberg and, therefore, had a greater willingness to pay an extraordinary patent fee in relation to that paid by foreign inventors who lived farther away from Wuerttemberg. Wuerttemberg's patent office might have exploited this fact by charging particularly high fees of inventors located in close distance. A third way to identify patentees with a high willingness to pay was to distinguish between patents of invention and patents of introduction. The patent authority awarded patents of introduction to persons who introduced an innovation that was already successful abroad for the first time in Wuerttemberg. Originally, the person who applied for a patent of introduction did not need authorization by the original foreign inventor (Dölemeyer 2015, p. 14). ${ }^{15}$ In 1842 ,

\footnotetext{
${ }^{14}$ Lehmann-Hasemeyer and Streb (2016) show that investors at the Berlin stock exchange expected a corporation's profits to correlate positively with its patenting activities.

${ }^{15}$ Many less developed countries that tried to catch up used this instrument. For the Spanish case, see Sáiz and Pretel (2013).
} 


\section{Wuerttemberg Patent Law in Administrative Practice 1079}

however, this rule changed at least with respect to foreign inventors that lived in the German Customs Union. Formally accepting the new principle of national treatment, Wuerttemberg agreed on granting patents of introduction only to those persons who had already patented the invention in question in another member state of the German Customs Union. ${ }^{16}$ In the following years, the original inventor often teamed up with a resident of Wuerttemberg to apply for a patent of introduction. It is conceivable that the patent authority assigned comparatively high patent fees to patents of introduction that protected inventions that had already proven their usefulness outside of Wuerttemberg.

Nineteenth-century legislators had deliberately introduced patent renewal fees in the hope that many patent holders who were not able to profitably exploit their patents would give them up early and make the new knowledge that was documented in the patent file publicly usable long before the originally assigned patent duration would have elapsed. That is why, in patent systems with renewal fees, such as that of Wuerttemberg, profitable patents can alternatively be identified by their life span (Schankerman and Pakes 1986; Streb, Baten, and Yin 2006). We assume that Wuerttemberg's patent authority inferred from the patent term applied for by an inventor on his individual expectations about his intended patent.

The second principle the patent authority of Wuerttemberg alleged to follow was motivated by protectionist reasoning and, therefore, only relevant for foreign patentees. Vischer (1875) claimed that the patent administration set an individual patent fee higher the more a resident of Wuerttemberg had to pay to keep a patent in force in the respective foreign inventor's country of origin (ICO). Similar to a trade war involving punitive tariffs, the patent authority apparently responded to high foreign patent fees for domestic inventors with high domestic patent fees for foreign ones. ${ }^{17}$ Even though Vischer (1875) did not admit it in his report, the members of the patent authority might have had very personal protectionist motives to discriminate against foreign inventors. In Wuerttemberg, the patent authority was a sub-committee of the so-called Centralstelle fuer Handel und Gewerbe, which was founded to support the ministry of the interior in matters of promotion of trade and industry. Although this committee included civil servants, the majority of its members were local businessmen who had been elected to the post by their peers. Among these, the entrepreneur Ferdinand

\footnotetext{
${ }^{16}$ See Article 3 of the Gesetz betreffend die Erfindungs- und Einführungspatente vom 29. Juni 1842, in Regierungsblatt für das Königreich Württemberg vom 8. Juli 1842.

${ }_{17}$ Clemens and Williamson (2004) argue that in the nineteenth-century world without international coordination raising tariffs to retaliate against an increase in foreign tariffs might have been a growth-enhancing activity.
} 
von Steinbeis stood out; he had dedicated himself to the industrialization of Wuerttemberg and headed the Centralstelle between 1856 and $1880 .{ }^{18}$ The local businessmen around Steinbeis might have used their influence to set comparatively high patent fees for foreign inventors in order to discourage them from acquiring a patent in Wuerttemberg or, if they still did, to keep it for a long time. If the local businessmen did follow this strategy, patent fees might have been especially high for patents that affected those industries that dominated the economy of Wuerttemberg.

Such a discriminatory strategy would have been illegal, however, if the foreign inventors resided within the borders of the Zollverein because, in 1842, Wurttemberg had committed itself by law to treat the inventors from the other countries of the Zollverein in the same way as its own subjects. ${ }^{19}$ Whether Wuerttemberg's patent authority complied with this legal principle in administrative practice is an open question that we will research in the following sections.

Thus, we consider that Wuerttemberg's patent authority strategically followed fiscal and protectionist motives when discriminating against foreign inventors. By fiscal motives, we mean the patent authority's attempt to raise public revenues, and by protectionist motives, its goal to facilitate the use of foreign technology by local businessmen. We explore fiscal motives by controlling for the number of World's Fair exhibits of a patentee's country of origin, a patent's life span, the existence of a joint border with Wuerttemberg, and a patent's status as a patent of introduction. For the possibility of protectionist motives, we will examine Wuerttemberg's industry structure and disparities of the international patent fees. The part of systematic excessive patent fees of foreigners, which these variables together cannot explain, will be captured by dummy variables that distinguish between patentees from other member states of the German Customs Union, from German states that did not become members of the German Customs Union, and from non-German countries. These dummies measure unobserved time-invariant determinants of discrimination such as political animosities.

\footnotetext{
${ }^{18}$ Ferdinand Steinbeis' (1807-1893) former career as an entrepreneur reached its peak in 1842 when he became managing director of the ironworks Stumm in Neunkirchen in the Saar region. As the head of the Centralstelle fuer Handel und Gewerbe, Steinbeis is especially credited for founding several trade schools. For a re-assessment of his lifetime achievement, see Kollmervon-Oheimb-Loup (1998). In the first half of the nineteenth century, quite similar to Steinbeis' activities, Prussian senior official Christian Peter Wilhelm Beuth promoted technology transfer to Prussia as part of his industrial policy. See Paulinyi (1992).

19 See Article 2 of the Gesetz betreffend die Erfindungs- und Einführungspatente vom 29. Juni 1842, in Regierungsblatt für das Königreich Württemberg vom 8. Juli 1842. On the level of the German Customs Union, this rule was a precursor of the principle of national treatment established in the Paris Convention of 1883.
} 


\section{Wuerttemberg Patent Law in Administrative Practice 1081}

\section{DATA}

To find out whether the patent authority of Wuerttemberg determined patent fees according to fiscal or protectionist motives, we need information about the individual patents. ${ }^{20}$ An unpublished register compiled by Hans Peter Münzenmayer, which is held by the Wirtschaftsarchiv Baden-Württemberg, provides details about the 1,141 patents the state of Wuerttemberg granted between 1818 and 1868. This information includes a patentee's name and place of residence as well as a patent's assigned and realized life span. Sometimes, a patentee's occupation is also known. Following Donges and Selgert (2019a), we assigned each patent to 1 of 24 industries (see Tables A3 and A4 in the Online Appendix) for which a Zollverein survey of 1861 provides employment data. ${ }^{21}$ In addition, we hand collected data about individual patent fees from the original letters patents that are shelved in the Staatsarchiv Ludwigsburg. Information is available for 723 out of 972 patents that were granted between 1844 and $1868 .{ }^{22}$ The availability of information on patent fees dictated the starting year of this subperiod. ${ }^{23}$ In contrast, it was our own decision not to consider patents granted after 1868 because the introduction of a nationwide patent law in 1877 systematically changed their assigned and realized life spans. If we compare the geographical distribution of patentees in our restricted sample of 723 patents with the one in the full sample, we find that differences are only small (see Table A2 in the Online Appendix). The years from 1844 to 1868 cover most of the period in which Wuerttemberg had promised not to discriminate against inventors from other member states of the German Customs Union.

Figure 1 shows that patenting activities were rather low until the end of the 1830s, stagnated at a slightly higher level in the 1840s and early $1850 \mathrm{~s}$, and began to rise substantially since the late 1850s. This development mirrors the economic development of Wuerttemberg whose industrialization gained momentum in the second half of the nineteenth century. ${ }^{24}$ Figure 1 also verifies that our subsample of patents from 1844 to 1868 covers the period of main patenting activities.

\footnotetext{
${ }^{20}$ Kollmer-von-Oheimb-Loup (2016) gives an overview about patenting activities in Wuerttemberg between 1818 and 1932.

${ }^{21}$ See Deutscher Zollverein (1864). The assignment was made in two steps. First, we allocated each patent based on its title to 1 of the 89 technological classes introduced by the Imperial Patent Office in 1877. Second, we used the mapping developed by Donges and Selgert (2019a) (see online-appendix ehr12703-sup-0001-SuppMat.docx) to match these 89 technological classes with the industries listed in the Zollverein survey.

${ }^{22}$ The data are published in Lehmann-Hasemeyer and Streb (2020).

${ }^{23}$ That is why we cannot analyze how the Wuerttemberg patent administration treated patent holders from other member states of the Zollverein before the principle of equal treatment was introduced in 1842 .

${ }^{24}$ See Kollmer-von Oheimb-Loup (2016, pp. 51-56).
} 


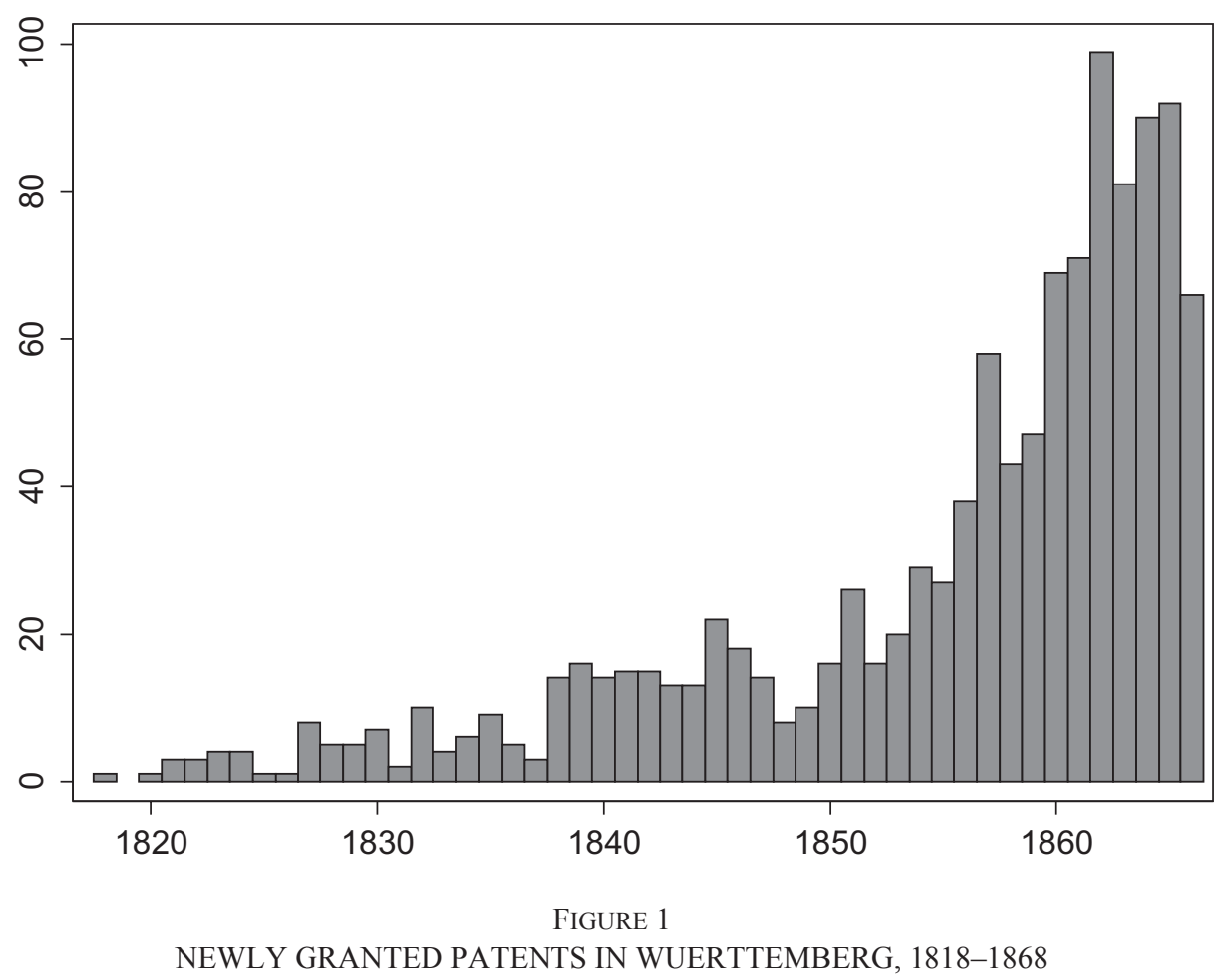

Source: Münzenmayer (no date).

Table 1 demonstrates that, on average, foreign inventors had to pay a much higher patent fee than the residents of Wuerttemberg did. Surprisingly, foreigners from non-German countries did not bear the highest patent fees. Instead, the extra financial burden was especially high for patentees who lived in German states that did not become a member of the German Customs Union (Zollverein).$^{25}$ Even inventors who resided within the borders of the Zollverein (but not in Wuerttemberg) had to pay a patent fee that was about 75 percent higher than the average patent fee of a resident from Wuerttemberg.

Figures 2 and 3 show how the distribution of patent holders across countries of origin and the origin-related patent fees changed over time. In total, we observe inventors from 31 different countries including the various independent German states. Two developments are noteworthy. First, the share of patent holders from Wuerttemberg fell to about 50 percent, while the respective shares of patent holders from other states of

\footnotetext{
${ }^{25}$ We assigned the states that joined the German Customs Union after 1834 to one of the other two groups until the date of their entry.
} 


\section{Wuerttemberg Patent Law in Administrative Practice 1083}

TABLE 1

AVERAGE PATENT FEE AND LIFE SPAN OF PATENTS IN WUERTTEMBERG, $1844-1868$

\begin{tabular}{lccc}
\hline \hline $\begin{array}{l}\text { Patentees' Country } \\
\text { of Residence }\end{array}$ & Annual Patent Fee & Assigned Life Span & Realized Life Span \\
\hline Wuerttemberg & $7 \mathrm{fl}$ & 6.4 years & 4.8 years \\
German Customs Union & $12.4 \mathrm{fl} * * *$ & 5 years*** & 3.6 years*** \\
$\begin{array}{l}\text { German states outside the } \\
\text { Customs Union }\end{array}$ & $16.5 \mathrm{fl} * * *$ & 6.5 years & 4 years \\
Non-German states & & & \\
\hline Total & $13.4 \mathrm{ff} * * *$ & 4.8 years & \\
\hline
\end{tabular}

a States that did not become part of the German Empire in 1871.

Note: Asterisks indicate whether the mean values are significantly different from Württemberg. Significance levels are $* * * p<0.01, * * p<0.05, * p<0.1$

Source: Own calculations based on patent fees taken from the original letters patents that are shelved in the Staatsarchiv Ludwigsburg.

the Zollverein and from foreign states rose to one-quarter each. Second, the average annual patent fee that patent holders both from other states of the Zollverein and from foreign states had to pay rose considerably in the $1850 \mathrm{~s}$, whereas the patent fees remained comparatively low for people from Wuerttemberg. Figure 4 presents the country-specific distribution of patent fees for the ten countries where most of the patentees resided. Patent fees differed considerably across countries and were especially high in France, Great Britain, and Saxony. Interestingly enough, Figure 4 also shows that inventors from less developed Bavaria had to deal with comparatively high patent fees. This observation suggests that the patent office of Wuerttemberg indeed assumed that inventors from neighboring countries were especially interested to sell their products in Wuerttemberg and, therefore, had a higher willingness to pay high fees.

Differences in the average life span of patents were less pronounced (see Table 1). Inventors were allowed to suggest the life span of their patent, which could be held up to ten years, ${ }^{26}$ and, according to Gehm (2001, p. 157), the patent authority usually accepted their proposals. An inventor, however, was not forced to hold his patent until it expired but could give it up earlier when keeping it seemed no longer worth the annual patent fee. The fact that the ex-ante assigned life span was mostly longer than the ex-post realized life span suggests that inventors' expectations about the future profitability of their inventions were often too optimistic.

${ }^{26}$ See Article 149 of the trade act of 1828. For a similar procedure in Italy, see Nuvolari and Vasta (2015). 


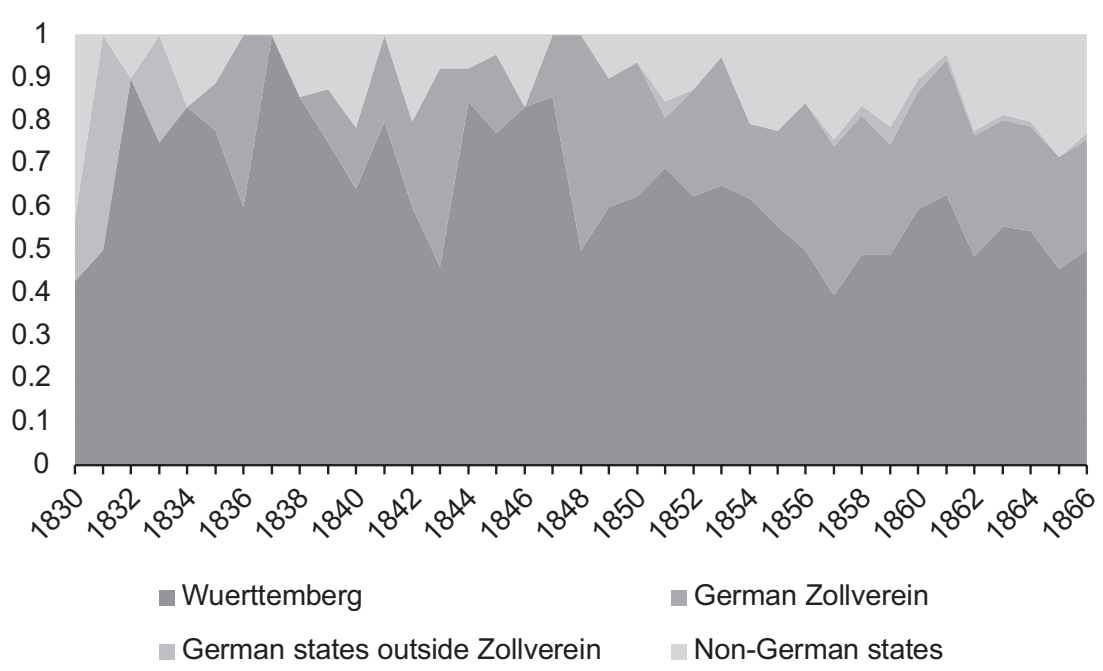

FIGURE 2

PERCENTAGE SHARE OF PATENT HOLDER'S COUNTRY OF ORIGIN

Source: Münzenmayer (no date).
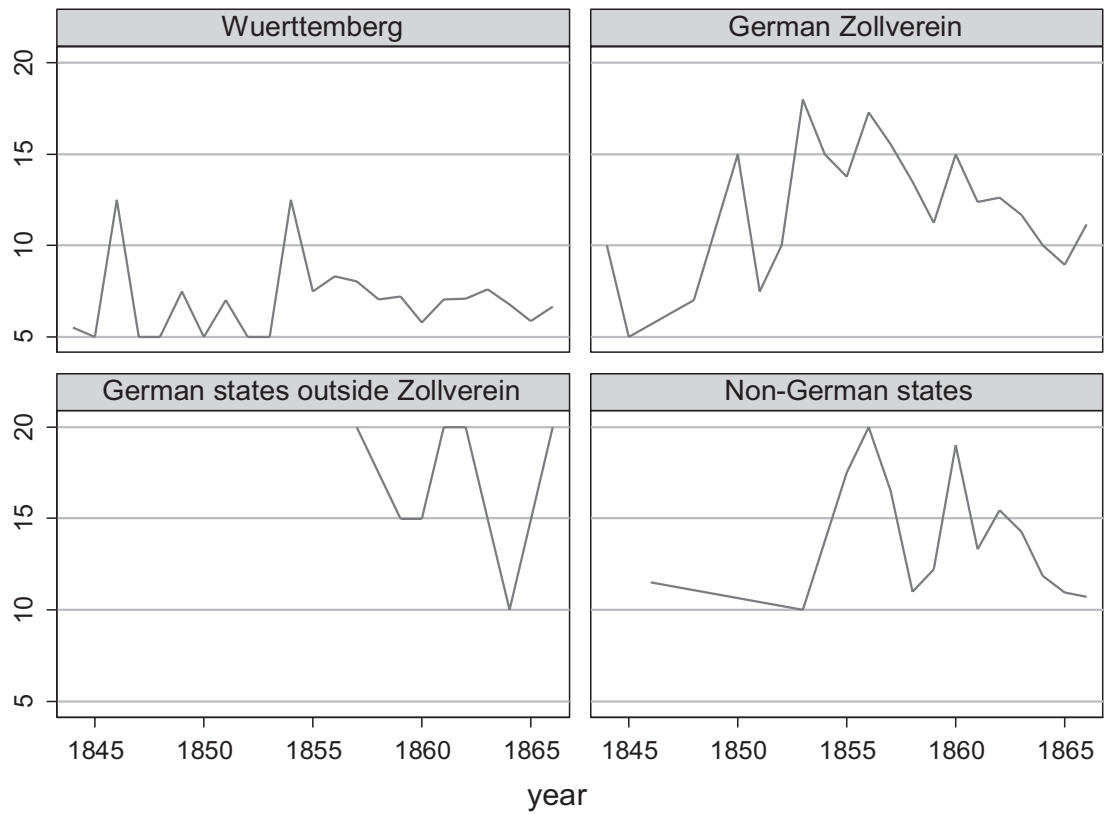

FIGURE 3

AVERAGE ANNUAL PATENT FEE CONDITIONAL ON THE PATENT HOLDER'S COUNTRY OF ORIGIN

Source: Fees and country of origin were collected from the original letters patents that are shelved in the Landesarchiv Baden-Württemberg, Abteilung Staatsarchiv Ludwigsburg E 170. 

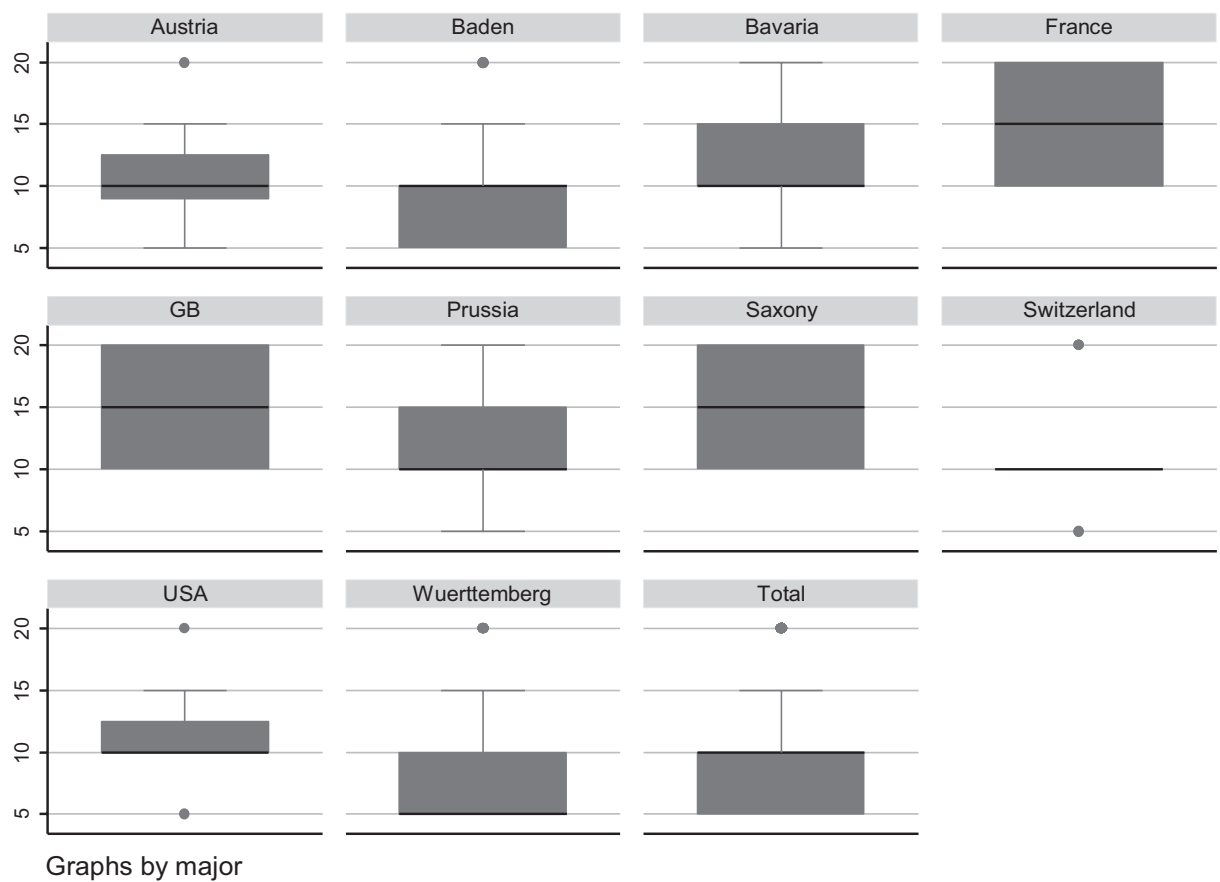

FIGURE 4

Notes: The figure shows the distribution of patent fees for the ten countries for which we observe more than nine patents with information on patent fees. Endpoints extend two-thirds the width of a box. The black line indicates the median, and the borders of the black box are the 25 and 75 quantiles. In the case of Switzerland, 65 percent of the patents had a fee of ten guilders per year. Only three patents came with a fee of 5 and only two with a fee of 20 guilders and are, thus, considered as outliers. Also note that in contrast to Table 2, Bavaria only covers the patents from inventors located in the proper territory of Bavaria. Inventors from Palatinate are excluded here. Source: Fees and country of origin were collected from the original letters patents that are shelved in the Landesarchiv Baden-Württemberg, Abteilung Staatsarchiv Ludwigsburg E 170.

Figure 5 illustrates the development of the patents' assigned and realized average life span over time. We observe a downward trend of the average assigned life span in the 1840s and 1850s. At first glance, this finding suggests that the patentees learned to form realistic expectations with regard to the future economic performance of their inventions. The average realized life span, however, dropped even faster, which means that even shortened patent terms turned out to be too optimistic.

Assuming that the number of a country's exhibits at World's Fairs formed the basis for a country's contemporary reputation as an innovator, we chose the London World's Fair of 1862 as a representative case study. Since 45 percent of the patents in our sample were granted before 1862 and the rest in that year or later, the London exhibition 


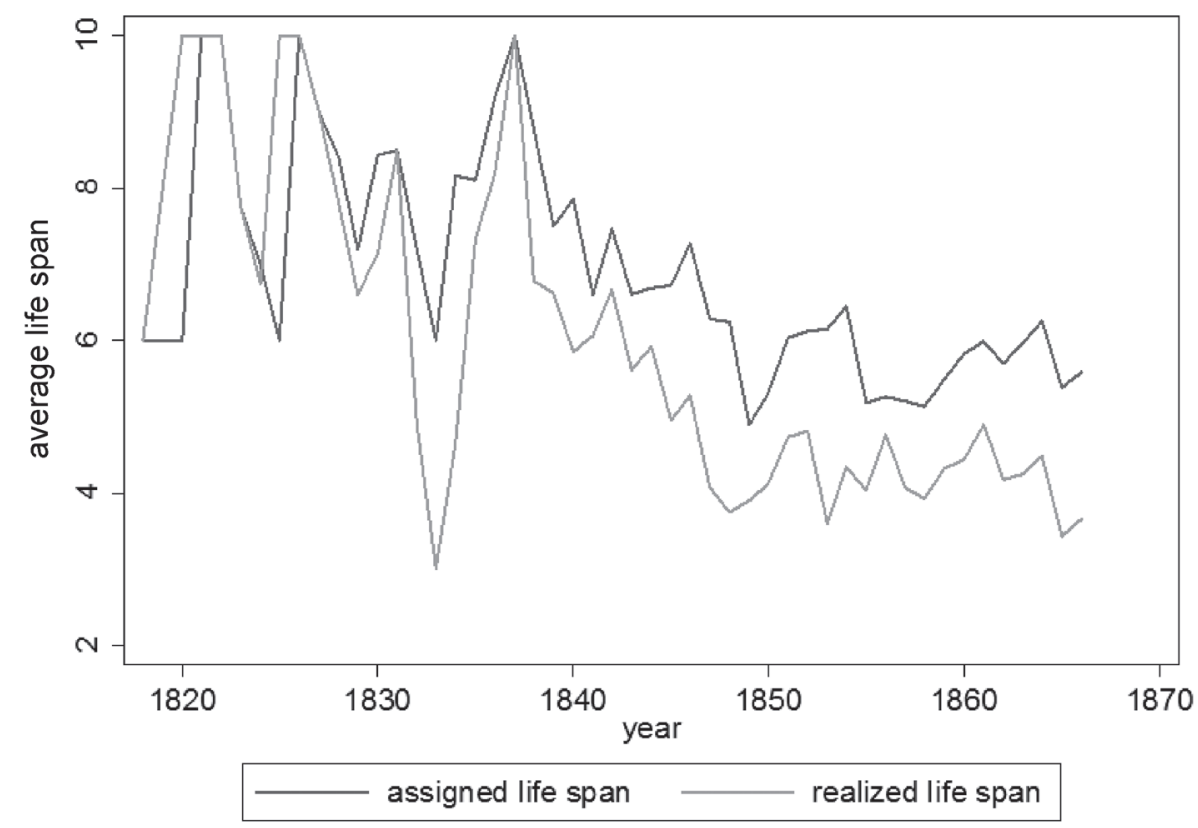

FIGURE 5

ASSIGNED AND REALIZED LIFE SPAN OF THE PATENTS GRANTED IN WUERTTEMBERG

Source: Münzenmayer (no date).

comes closest in time to the median of our time series. ${ }^{27}$ We counted each country's exhibits listed in the original catalogue of 1862 (Authority of Her Majesty's Commissioners 1862). To test for retaliation, we collected information about the distribution of international patent fees with the help of several sources including Lerner (2000). ${ }^{28}$ Since we assigned each patent to one of the industries listed in the Zollverein survey, we can use data from this source to examine whether patent fees increased with the employment share of the Wuerttemberg industry that was mostly affected by a particular patent.

Table 2 presents descriptive statistics from the perspective of an ICO. In our period of observation, inventors from Great Britain, for example, held 15 patents in Wuerttemberg for which they paid an average annual patent fee of about 16 South German guilders (or 7 U.S. dollars). At the same time, the annual patent fee for a British patent, which all inventors had to pay regardless of their country of origin, came to 153 guilders

\footnotetext{
${ }^{27}$ Other World's Fairs took place in our period of observation, namely, London (1851), New York (1853), Paris (1855), and again Paris (1867).

${ }^{28}$ Some patents were held by several patent holders of different nationalities. In these cases, we have selected the highest (max) country-specific patent fees and number of world exhibits.
} 


\section{Wuerttemberg Patent Law in Administrative Practice 1087}

\section{TABLE 2}

DESCRIPTIVE STATISTICS DEPENDING ON ICO

\begin{tabular}{|c|c|c|c|c|}
\hline ICO & $\begin{array}{l}\text { Annual } \\
\text { Patent } \\
\text { Fee in } \\
\text { ICO in } \\
\text { fl and }(\$)^{\mathrm{a}}\end{array}$ & $\begin{array}{l}\text { Number of } \\
\text { Exhibits } \\
\text { of ICO at } \\
\text { London World's } \\
\text { Fair of } 1862\end{array}$ & $\begin{array}{c}\text { Annual } \\
\text { Patent } \\
\text { Fee in } \\
\text { Wuerttemberg } \\
\text { Depending } \\
\text { on ICO } \\
\text { in } \mathrm{fl} \text { and }(\$)^{\mathrm{a}}\end{array}$ & $\begin{array}{c}\text { Number of } \\
\text { Patents of } \\
\text { ICO in } \\
\text { Wuerttemberg } \\
\text { with Information } \\
\text { on Fees }\end{array}$ \\
\hline Russia incl. Finland & $184.5(77.5)$ & 723 & $10.8(4.5)$ & 6 \\
\hline Great Britain & $153(64.3)$ & 5,785 & $15.7(6.6)$ & 15 \\
\hline Austria & $123(51.7)$ & 1,411 & $11.4(4.5)$ & 13 \\
\hline Belgium & $66.7(28)$ & 815 & $7.5(3.2)$ & 2 \\
\hline $\begin{array}{l}\text { Netherlands incl. } \\
\text { Luxembourg }\end{array}$ & 49 (20.6) & 284 & $10(4.2)$ & 2 \\
\hline Spain & $47.6(20)$ & 1,132 & $13.8(5.8)$ & 4 \\
\hline France & $47.6(20)$ & 3,092 & $14.8(6.2)$ & 70 \\
\hline Italy & $42.9(18)$ & 2,107 & $12(5)$ & 5 \\
\hline United States & $\begin{array}{c}30.8(13) \\
\text { until 1861, } \\
4.9(2) \\
\text { afterward }\end{array}$ & 131 & $11.3(4.7)$ & 8 \\
\hline $\begin{array}{l}\text { Bavaria (since 1853) } \\
\text { incl. Palatine }\end{array}$ & $12.2(5.1)$ & 128 & $13.1(5.5)$ & 24 \\
\hline Baden & $10(4.2)$ & 92 & $9.3(3.9)$ & 30 \\
\hline Wuerttemberg & $9.8(4.1)$ & 195 & $7(2.9)$ & 389 \\
\hline Saxony & $7.9(3.3)$ & 199 & $15(6.3)$ & 24 \\
\hline Hanover & $6.5(2.7)$ & 83 & $15(6.3)$ & 3 \\
\hline Hesse Nassau & $7(2.9)$ & 18 & $8.8(3.7)$ & 4 \\
\hline Sweden & $6.3(2.6)$ & 512 & $10(4.2)$ & 2 \\
\hline Hesse-Darmstadt & $3.9(1.6)$ & 125 & $10.6(4.5)$ & 9 \\
\hline Frankfurt/Main & $3(1.3)$ & 28 & $14(5.9)$ & 5 \\
\hline Kur Hesse (Hesse-Kassel) & $1.75(0.7)$ & 18 & $15(6.3)$ & 2 \\
\hline Prussia & $0.9(0.4)$ & 1,198 & $12.7(5.3)$ & 98 \\
\hline Hamburg & $0(0)$ & 138 & $15(7.1)$ & 2 \\
\hline Schleswig & $0(0)$ & $25^{\mathrm{b}}$ & $20(8.4)$ & 1 \\
\hline Switzerland & $0(0)$ & 387 & $11.4(4.8)$ & 14 \\
\hline
\end{tabular}

${ }^{a}$ One South German guilder (fl) equaled 0.42 U.S. dollars (\$). ${ }^{\mathrm{b}}$ Identified among the Danish exhibits. Sources: Patent fees and duration: Andersson and Tell (2019, Table 1), Donges and Selgert (2019b, Table 1), Lerner (2000, Tables 2 and 3), Nicholas (2011, p. 331), and Sáiz and Amengual (2013, Table 1). The patent fees of Austria were taken from the Kaiserliches Patent vom 15. August 1852. Because of missing information, we excluded Algeria, Brunswick, Oldenburg, Sardinia, and the Vatican State. World's Fair exhibits: Authority of Her Majesty’s Commissioners (1862). 
(or 64 dollars). Table 2 also reveals that Great Britain led the list of the most innovative countries in the respect that its inhabitants showed at the London World's Fair 5,785 different exhibits.

\section{IDENTIFICATION STRATEGY}

To test whether Wuerttemberg's patent authority strategically followed fiscal and protectionist motives when discriminating against foreign inventors, we need to make assumptions about the indicators that contemporaries used to identify foreign inventions that were either especially suitable for rent extraction or a worthwhile target of domestic imitation efforts. With respect to fiscal motives, we have already suggested that Wuerttemberg's patent authority relied on four different methods to estimate foreign patentees' willingness to pay high patent fees. In the following regression models, we measure a country's reputation as an innovator with the number of this country's exhibits at the London World's Fair of 1862 and interpret a long realized life span of a patent as an additional indicator of its comparatively high profitability. In addition, we introduce two dummy variables. The first one takes the value one if an inventor's country of residence shared a common border with Wuerttemberg, and the second becomes one if a patent of introduction was granted.

An important argument against using a patent's realized life span as an indicator for its profitability is that we must assume reverse causality. For protectionist reasons, the patent authority might have applied the method of high patent fees to persuade foreign patent holders to give up their patents prematurely. To deal with this endogeneity problem, we experiment with using the ex-ante assigned life span instead of the ex-post realized life span in our regression models. The former variable (which normally corresponded to the inventor's proposal) indicates an inventor's individual expectation about the future profitability of his patent independent from the patent fee of which he only became aware when the patent authority granted him the patent. Just as important is the fact that when the patent authority set the fee, it also did not know the patent's eventual life span but only the period the inventor planned to keep the patent.

For the possibility of protectionist motives, we make use of two indicators. First, we explore whether Wuerttemberg's patent authority retaliated against high patent fees abroad. There is no reason to fear that the patent fee that people from Wuerttemberg had to pay abroad was an endogenous variable. The foreign patent systems did not provide for a patentspecific differentiation of patent fees so that foreign patent authorities 


\section{Wuerttemberg Patent Law in Administrative Practice 1089}

lacked the possibility of retaliating against inventors from Wuerttemberg when they realized that their own citizens were discriminated against in this German state. Second, we have a closer look at patents that had the potential to change production in one of Wuerttemberg's industries that employed the most workers. To explore whether an invention that affected Wuerttemberg's most important industries triggered an increase in patent fees if the patentee was a foreigner, we interact the employment share of the affected industry with a dummy variable that assumes the value one if the patentee was a foreigner. In addition, we introduce dummy variables that distinguish between patentees from other member states of the German Customs Union, from German states that did not become members of the German Customs Union, and from non-German countries.

Thus, we estimate an ordinary least squares (OLS) regression, in which the variables we aim at explaining are the assigned annual patent fees. In addition to our main explanatory variables, life span (realized or assigned), retaliation fee, World's Fair exhibits, employment shares per industry and dummies for joint borders, patents of introduction, and place of origin, we control for year fixed effects, distance to the patent office, and overall number of granted patents per year. ${ }^{29}$ The standard errors are clustered by sector.

We suspect that one of the main reasons for the high fees for foreigners was to induce them to give up their patents early. To find out whether this assumption is true, we also examine the determinants of early patent termination. This is done in two ways. First, we apply a logit regression, in which the dependent variable is equal to one if the assigned life span is longer than the realized life span, and zero otherwise. Second, to use all the information available, we run OLS regressions in which the dependent variable is the difference between the assigned life span and the realized life span. The greater this difference, the earlier a patentee terminated his patent before its originally determined expiration date. In both types of regression, we are especially interested in the interaction term between a dummy variable that is equal to one for all inventors from outside Wuerttemberg and the patent fee they had to remit.

\section{EMPIRICAL RESULTS}

The results in Table 3 are consistent with the argument that Wuerttemberg's patent authority was guided by fiscal objectives when calculating patent fees. The assigned patent fee significantly rose with the

\footnotetext{
${ }^{29}$ For descriptive statistics, see Table A1 in the Online Appendix.
} 


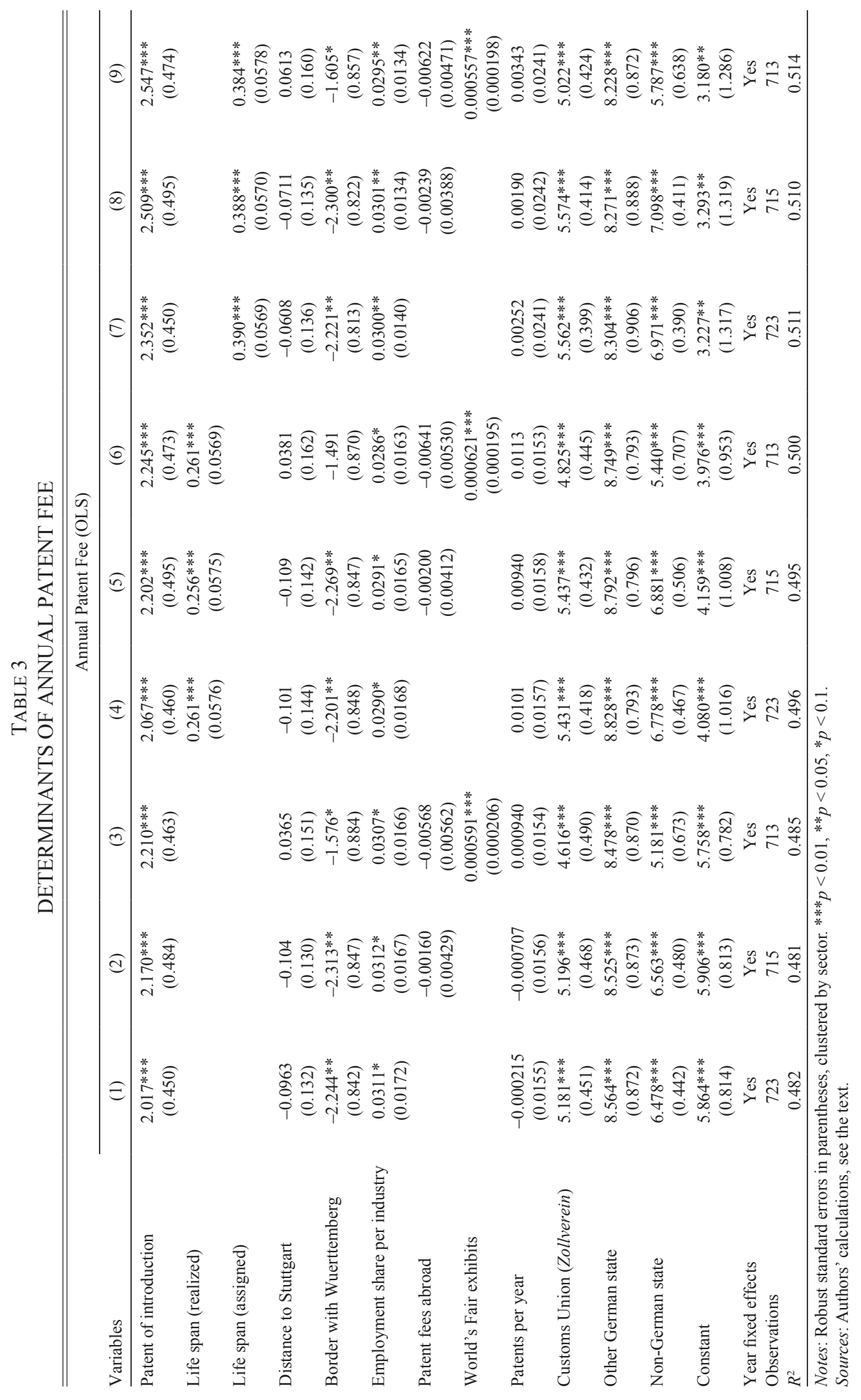




\section{Wuerttemberg Patent Law in Administrative Practice 1091}

number of World's Fair exhibits of an ICO, which implies that the patent authority believed that the profitability of an individual invention was positively correlated with its home country's reputation as an innovator. According to the estimates, a one-standard-deviation increase in World's Fair exhibits led to a 0.13-standard-deviation change in patent fee. The patent fee also rose by a 0.19 standard deviation with a one-standarddeviation change in the assigned life span. The finding that the coefficient of the assigned life span is higher than the coefficient of the realized life span supports our assumption that the latter variable is endogenous. We also want to stress that a patent of introduction was about two guilders per year more expensive than a patent of invention, which corresponds to about a 0.4-standard-deviation change of the patent fee. This result shows that the patent authority clearly understood that the introduction of an innovation that had already proven its usefulness outside of Wuerttemberg was, on average, more profitable than a local invention still awaiting market testing. ${ }^{30}$

Protectionist motives are also consistent with our findings. In Table 3 , we find significantly higher patent fees in industries with a higher Wuerttemberg employment share. A one-standard-deviation increase in employment share is estimated to have led to a 0.05 -standard-deviation change in patent fee. In Table 4, we interact the employment share with a dummy variable that assumes the value one if the patentee was a foreigner. The positive and significant coefficient of this interaction term proves that the increase in patent fees that can be explained with a Wuerttemberg industry's high employment share was primarily directed against foreign patentees. In contrast, we did not find any statistical evidence for the patent authority's official claim that it retaliated against high patent fees abroad. The effect of a joint border with Wuerttemberg is negative and not positive as expected. This finding seems to imply that the patent authority preferred inventors from direct neighboring countries.

Table 3 also shows that even after controlling for various factors that measure the patent authority's fiscal and protectionist motives for discrimination against specific patentees, an ICO still explains large parts of the variance of patent fees. A German patentee, who lived outside the German Customs Union, had to pay a patent fee that was more than eight guilders higher than the one a resident of Wuerttemberg had to remit. A

\footnotetext{
${ }^{30}$ In another model, not presented in Table 3, we tested the idea that an experienced inventor, who had successfully applied for other patents in the past or had a network of co-patentees, produced patents of a higher quality and was, therefore, charged higher patent fees. The two variables "Number of patents by inventor" and "Number of fellow inventors" turned out to be insignificant, however.
} 
TABLE 4

INTERACTION EFFECT OF VESTED INTEREST AND FOREIGN PATENTEE

\begin{tabular}{|c|c|c|c|c|c|c|}
\hline \multirow[b]{2}{*}{ Variables } & \multicolumn{6}{|c|}{ Annual Patent Fee (OLS) } \\
\hline & (1) & (2) & (3) & (4) & (5) & (6) \\
\hline $\begin{array}{l}\text { Foreign ( }=1 \text { if inventor } \\
\text { not from Wuerttemberg) }\end{array}$ & $\begin{array}{l}4.987^{* * *} \\
(0.500)\end{array}$ & $\begin{array}{l}4.987 * * * \\
(0.500)\end{array}$ & $\begin{array}{c}4.746 * * * \\
(0.547)\end{array}$ & $\begin{array}{l}5.351^{* * *} \\
(0.432)\end{array}$ & $\begin{array}{l}5.351^{* * *} \\
(0.432)\end{array}$ & $\begin{array}{l}5.121 * * * \\
(0.493)\end{array}$ \\
\hline $\begin{array}{l}\text { Employment share } \\
\text { per industry }\end{array}$ & $\begin{array}{l}0.0322 * \\
(0.0165)\end{array}$ & $\begin{array}{l}0.0322 * \\
(0.0165)\end{array}$ & $\begin{array}{c}0.0116 \\
(0.0232)\end{array}$ & $\begin{array}{l}0.0312 * * \\
(0.0132)\end{array}$ & $\begin{array}{c}0.0312 * * \\
(0.0132)\end{array}$ & $\begin{array}{c}0.0117 \\
(0.0177)\end{array}$ \\
\hline $\begin{array}{l}\text { Foreign } \times \text { Employment } \\
\text { share per industry }\end{array}$ & & & $\begin{array}{l}0.0399 * * \\
(0.0176)\end{array}$ & & & $\begin{array}{l}0.0379 * * \\
(0.0144)\end{array}$ \\
\hline Life span (assigned) & & & & $\begin{array}{l}0.395 * * * \\
(0.0618)\end{array}$ & $\begin{array}{l}0.395 * * * \\
(0.0618)\end{array}$ & $\begin{array}{l}0.394 * * * \\
(0.0614)\end{array}$ \\
\hline Patents per year & $\begin{array}{l}0.00236 \\
(0.0146)\end{array}$ & $\begin{array}{l}0.00236 \\
(0.0146)\end{array}$ & $\begin{array}{l}0.00113 \\
(0.0143)\end{array}$ & $\begin{array}{l}0.00536 \\
(0.0236)\end{array}$ & $\begin{array}{l}0.00536 \\
(0.0236)\end{array}$ & $\begin{array}{l}0.00419 \\
(0.0231)\end{array}$ \\
\hline Patent of introduction & $\begin{array}{c}2.186 * * * \\
(0.516)\end{array}$ & $\begin{array}{c}2.186^{* * *} \\
(0.516)\end{array}$ & $\begin{array}{c}2.158 * * * \\
(0.523)\end{array}$ & $\begin{array}{c}2.506 * * * \\
(0.508)\end{array}$ & $\begin{array}{c}2.506 * * * \\
(0.508)\end{array}$ & $\begin{array}{c}2.478 * * * \\
(0.517)\end{array}$ \\
\hline Distance to Stuttgart & $\begin{array}{l}0.0421 \\
(0.144)\end{array}$ & $\begin{array}{l}0.0421 \\
(0.144)\end{array}$ & $\begin{array}{l}0.0460 \\
(0.145)\end{array}$ & $\begin{array}{l}0.0962 \\
(0.146)\end{array}$ & $\begin{array}{l}0.0962 \\
(0.146)\end{array}$ & $\begin{array}{l}0.0999 \\
(0.148)\end{array}$ \\
\hline Border with Wuerttemberg & $\begin{array}{c}-1.803^{*} \\
(0.973)\end{array}$ & $\begin{array}{c}-1.803 * \\
(0.973)\end{array}$ & $\begin{array}{c}-1.806^{*} \\
(0.975)\end{array}$ & $\begin{array}{c}-1.732 * \\
(0.931)\end{array}$ & $\begin{array}{c}-1.732 * \\
(0.931)\end{array}$ & $\begin{array}{r}-1.735^{*} \\
(0.932)\end{array}$ \\
\hline Patent fees abroad & $\begin{array}{l}-0.00229 \\
(0.00548)\end{array}$ & $\begin{array}{l}-0.00229 \\
(0.00548)\end{array}$ & $\begin{array}{l}-0.00236 \\
(0.00545)\end{array}$ & $\begin{array}{l}-0.00225 \\
(0.00518)\end{array}$ & $\begin{array}{l}-0.00225 \\
(0.00518)\end{array}$ & $\begin{array}{l}-0.00231 \\
(0.00515)\end{array}$ \\
\hline World's Fair exhibits & $\begin{array}{l}0.000550^{* *} \\
(0.000200)\end{array}$ & $\begin{array}{l}0.000550^{* *} \\
(0.000200)\end{array}$ & $\begin{array}{l}0.000542 * * \\
(0.000198)\end{array}$ & $\begin{array}{c}0.000572 * * * \\
(0.000180)\end{array}$ & $\begin{array}{c}0.000572 * * * \\
(0.000180)\end{array}$ & $\begin{array}{c}0.000565^{* * *} \\
(0.000177)\end{array}$ \\
\hline Constant & $\begin{array}{c}5.653^{* * * *} \\
(0.768)\end{array}$ & $\begin{array}{c}5.653 * * * \\
(0.768)\end{array}$ & $\begin{array}{c}5.849 * * * \\
(0.751)\end{array}$ & $\begin{array}{l}2.964 * * \\
(1.278)\end{array}$ & $\begin{array}{l}2.964 * * \\
(1.278)\end{array}$ & $\begin{array}{l}3.155^{* *} \\
(1.236)\end{array}$ \\
\hline Year fixed effects & Yes & Yes & Yes & Yes & Yes & Yes \\
\hline Observations & 713 & 713 & 713 & 713 & 713 & 713 \\
\hline$R^{2}$ & 0.478 & 0.478 & 0.479 & 0.508 & 0.508 & 0.509 \\
\hline
\end{tabular}

Notes: Robust standard errors in parentheses, clustered by sector. ${ }^{* *} p<0.01,{ }^{* *} p<0.05,{ }^{*} p<0.1$.

Sources: Authors' calculations, see the text.

non-German patentee had to pay about six guilders more, and even patentees from within the Zollverein, who were allegedly treated the same as locals, faced an excess patent fee of more than five guilders.

Table 5 answers the question of whether comparatively high patent fees pushed foreign inventors out of the market of Wuerttemberg. Our most intriguing finding is the significant positive coefficient of the interaction term between foreign and patent fee in model 6 . It suggests that patents from outside Wuerttemberg had a shorter realized life span when they had to pay higher fees. Foreigners also had a higher probability of giving up their patents prematurely (before the assigned time) with high patent fees (model 4), although the estimated effect in this case is not significant. Moreover, inventors from the countries that excelled with the most World's Fair exhibits generally seemed to face a higher probability of giving up their intellectual property rights ahead of time. An increase 


\section{Wuerttemberg Patent Law in Administrative Practice 1093}

TABLE 5

DETERMINANTS OF PATENT TERMINATION

\begin{tabular}{|c|c|c|c|c|c|c|}
\hline \multirow[b]{2}{*}{ Variables } & \multirow{2}{*}{$\begin{array}{c}\text { Canceled } \\
(1) \\
\text { Logit }\end{array}$} & \multirow{2}{*}{$\begin{array}{c}\text { Difference } \\
\text { Assigned and } \\
\text { Realized } \\
\text { Life Span } \\
\text { (2) } \\
\text { OLS }\end{array}$} & \multicolumn{2}{|c|}{ Canceled } & \multicolumn{2}{|c|}{$\begin{array}{l}\text { Difference Assigned and } \\
\text { Realized Life Span }\end{array}$} \\
\hline & & & $\begin{array}{l}(3) \\
\text { Logit }\end{array}$ & $\begin{array}{l}(4) \\
\text { Logit }\end{array}$ & $\begin{array}{l}(5) \\
\text { OLS }\end{array}$ & $\begin{array}{l}(6) \\
\text { OLS }\end{array}$ \\
\hline Patent fee & $\begin{array}{l}-0.0263 \\
(0.0242)\end{array}$ & $\begin{array}{l}-0.0320 * \\
(0.0183)\end{array}$ & $\begin{array}{l}-0.0261 \\
(0.0234)\end{array}$ & $\begin{array}{l}-0.0547 \\
(0.0380)\end{array}$ & $\begin{array}{l}-0.0275 \\
(0.0177)\end{array}$ & $\begin{array}{c}-0.108 * * * \\
(0.0331)\end{array}$ \\
\hline $\begin{array}{l}\text { All foreign = } 1 \\
\quad(\text { Württemberg = 0) }\end{array}$ & & & $\begin{array}{c}0.349 \\
(0.387)\end{array}$ & $\begin{array}{c}-0.00112 \\
(0.584)\end{array}$ & $\begin{array}{c}0.373 \\
(0.352)\end{array}$ & $\begin{array}{l}-0.685 \\
(0.558)\end{array}$ \\
\hline $\begin{array}{l}\text { All foreign } \times \text { Patent } \\
\text { fee }\end{array}$ & & & & $\begin{array}{c}0.0419 \\
(0.0472)\end{array}$ & & $\begin{array}{l}0.121 * * * \\
(0.0398)\end{array}$ \\
\hline Patent of introduction & $\begin{array}{c}-0.858 * * * \\
(0.236)\end{array}$ & $\begin{array}{l}-0.275^{*} \\
(0.145)\end{array}$ & $\begin{array}{c}-0.803^{* * *} \\
(0.206)\end{array}$ & $\begin{array}{c}-0.797 * * * \\
(0.210)\end{array}$ & $\begin{array}{l}-0.247 * \\
(0.133)\end{array}$ & $\begin{array}{l}-0.234 \\
(0.138)\end{array}$ \\
\hline World Fair's exhibits & $\begin{array}{c}0.000307 * * * \\
(9.52 \mathrm{e}-05)\end{array}$ & $\begin{array}{c}0.000202 * * * \\
(6.88 \mathrm{e}-05)\end{array}$ & $\begin{array}{l}0.000241^{* *} \\
(0.000100)\end{array}$ & $\begin{array}{c}0.000232 * * \\
(0.000102)\end{array}$ & $\begin{array}{c}0.000131 \\
(8.36 \mathrm{e}-05)\end{array}$ & $\begin{array}{c}0.000111 \\
(8.97 \mathrm{e}-05)\end{array}$ \\
\hline Patent fees abroad & $\begin{array}{l}-0.00130 \\
(0.00304)\end{array}$ & $\begin{array}{l}-0.00182 \\
(0.00217)\end{array}$ & $\begin{array}{l}-0.00285 \\
(0.00281)\end{array}$ & $\begin{array}{l}-0.00282 \\
(0.00278)\end{array}$ & $\begin{array}{l}-0.00210 \\
(0.00188)\end{array}$ & $\begin{array}{l}-0.00209 \\
(0.00181)\end{array}$ \\
\hline Distance to Stuttgart & $\begin{array}{l}-0.00305 \\
(0.0924)\end{array}$ & $\begin{array}{l}-0.0155 \\
(0.0546)\end{array}$ & $\begin{array}{l}-0.0414 \\
(0.0873)\end{array}$ & $\begin{array}{l}-0.0400 \\
(0.0848)\end{array}$ & $\begin{array}{l}-0.0462 \\
(0.0477)\end{array}$ & $\begin{array}{l}-0.0415 \\
(0.0417)\end{array}$ \\
\hline $\begin{array}{l}\text { Border to } \\
\text { Wuerttemberg }\end{array}$ & $\begin{array}{l}0.623 * * \\
(0.249)\end{array}$ & $\begin{array}{c}0.478 \\
(0.342)\end{array}$ & $\begin{array}{l}0.513 * \\
(0.276)\end{array}$ & $\begin{array}{l}0.540^{*} \\
(0.279)\end{array}$ & $\begin{array}{c}0.335 \\
(0.389)\end{array}$ & $\begin{array}{c}0.430 \\
(0.400)\end{array}$ \\
\hline Patents per year & $\begin{array}{l}-0.00927 \\
(0.0191)\end{array}$ & $\begin{array}{c}0.0343 \\
(0.0412)\end{array}$ & $\begin{array}{l}-0.0102 \\
(0.0195)\end{array}$ & $\begin{array}{l}-0.00971 \\
(0.0195)\end{array}$ & $\begin{array}{c}0.0339 \\
(0.0411)\end{array}$ & $\begin{array}{c}0.0352 \\
(0.0411)\end{array}$ \\
\hline Life span (assigned) & $\begin{array}{c}0.168^{* * *} \\
(0.0389)\end{array}$ & $\begin{array}{c}0.424 * * * \\
(0.0411)\end{array}$ & $\begin{array}{c}0.171 * * * \\
(0.0377)\end{array}$ & $\begin{array}{c}0.178 * * * \\
(0.0378)\end{array}$ & $\begin{array}{c}0.430 * * * \\
(0.0441)\end{array}$ & $\begin{array}{c}0.449 * * * \\
(0.0432)\end{array}$ \\
\hline $\begin{array}{c}\text { Customs Union } \\
\text { (Zollverein) }\end{array}$ & $\begin{array}{c}0.337 \\
(0.392)\end{array}$ & $\begin{array}{c}0.273 \\
(0.315)\end{array}$ & & & & \\
\hline Other German state & $\begin{array}{c}0.652 \\
(0.685)\end{array}$ & $\begin{array}{l}1.644 * \\
(0.863)\end{array}$ & & & & \\
\hline Non-German state & $\begin{array}{l}-0.0352 \\
(0.458)\end{array}$ & $\begin{array}{c}0.117 \\
(0.390)\end{array}$ & & & & \\
\hline Constant & $\begin{array}{l}-0.416 \\
(1.197)\end{array}$ & $\begin{array}{l}-2.687 \\
(2.755)\end{array}$ & $\begin{array}{l}-0.373 \\
(1.230)\end{array}$ & $\begin{array}{l}-0.242 \\
(1.282)\end{array}$ & $\begin{array}{l}-2.726 \\
(2.751)\end{array}$ & $\begin{array}{l}-2.349 \\
(2.781)\end{array}$ \\
\hline $\begin{array}{l}\text { Year and sector } \\
\text { dummies }\end{array}$ & Yes & Yes & Yes & Yes & Yes & Yes \\
\hline Observations & 704 & 713 & 704 & 704 & 713 & 713 \\
\hline$R^{2}$ & & 0.284 & & & 0.280 & 0.289 \\
\hline
\end{tabular}

Notes: Robust standard errors in parentheses, clustered by sector. ${ }^{* * *} p<0.01,{ }^{* *} p<0.05,{ }^{*} p<0.1$.

Sources: Authors' calculations, see the text. 
of one standard deviation in World's Fair exhibits (about 1,113 exhibits) raises the difference between assigned and realized life span by about three months ( 0.1 times the standard deviation). This finding again indicates that the desired effect of discrimination did, in fact, occur: Foreign inventors were pushed out of patent protection. The lower cancellation rates of patents of introduction supports our assumption that they presented on average more useful innovations than patents of invention. Everything else equal, patents of introduction are estimated to reduce the difference between assigned and realized life span by about 3 months. That the probability of cancellation is positively correlated with the assigned life span is a rather mechanical relationship: The longer the assigned life span, the more opportunities a patentee had to cancel his patent before the assigned term elapsed.

To support our main argument, we conclude with a thought experiment assuming that the assigned patent fees correctly reflected the value of the individual patents. If that were true, the patent authority could have only discriminated against foreigners by granting them a comparatively shorter patent term. To explore the determinants of the assigned life span, we divided the historical patent population into four subgroups according to their patent fees. The first subgroup, for example, only contains patents with an assigned annual patent fee of 20 guilders. Again, the coefficients are estimated with OLS and standard errors are clustered by sector. Table 6 reveals that given a fixed patent fee, inventors who resided within the Zollverein, from other German states, and in non-German states got a shorter assigned patent term than inventors from Wuertemberg, meaning that their patent protection was weaker. The significantly shorter span for inventors from the Zollverein and non-German states is particularly striking and is precisely estimated in most patent fee groups.

\section{DISCUSSION}

In the period of patent discrimination analyzed in the preceding sections, Wuerttemberg started to catch up to more advanced member states of the German Customs Union. The multitude of factors that had the potential to foster such a convergence prevents us from establishing a causal link between patent policy and growth in the context of our isolated case study. Various other historical studies that assert that a government could ignite industrialization by facilitating the imitation of foreign technology provide indirect support. Eric Schiff (1971), for example, argues that Dutch firms profited from the abolition of the domestic patent in 1869, which averted foreign inventors from acquiring 


\section{Wuerttemberg Patent Law in Administrative Practice 1095}

TABLE 6

DETERMINANTS OF ASSIGNED LIFE SPAN

\begin{tabular}{|c|c|c|c|c|}
\hline Variables & $\begin{array}{c}\text { Patent Fee }=20 \mathrm{fl} \\
\text { (1) }\end{array}$ & $\begin{array}{c}\text { Patent Fee }=15 \mathrm{fl} \\
\text { (2) }\end{array}$ & $\begin{array}{c}\text { Patent } \mathrm{Fee}=10 \mathrm{fl} \\
\text { (3) }\end{array}$ & $\begin{array}{c}\text { Patent Fee }=5 \mathrm{fl} \\
\text { (4) }\end{array}$ \\
\hline $\begin{array}{l}\text { Patent of } \\
\text { introduction }\end{array}$ & $\begin{array}{l}-0.591 \\
(0.647)\end{array}$ & $\begin{array}{c}0.237 \\
(1.139)\end{array}$ & $\begin{array}{c}-1.746^{* * *} \\
(0.385)\end{array}$ & $\begin{array}{l}-0.495 \\
(0.644)\end{array}$ \\
\hline World Fair's exhibits & $\begin{array}{c}2.13 \mathrm{e}-05 \\
(0.000192)\end{array}$ & $\begin{array}{c}0.000158 \\
(0.000796)\end{array}$ & $\begin{array}{c}5.52 \mathrm{e}-05 \\
(0.000193)\end{array}$ & $\begin{array}{c}0.000103 \\
(0.000401)\end{array}$ \\
\hline Patent fees abroad & $\begin{array}{c}0.00557 * * \\
(0.00232)\end{array}$ & $\begin{array}{c}0.0235 \\
(0.0285)\end{array}$ & $\begin{array}{c}0.00367 \\
(0.00593)\end{array}$ & $\begin{array}{l}-0.0131^{*} \\
(0.00643)\end{array}$ \\
\hline Distance to Stuttgart & $\begin{array}{l}0.0534 \\
(0.290)\end{array}$ & $\begin{array}{c}0.151 \\
(0.338)\end{array}$ & $\begin{array}{l}-0.145^{*} \\
(0.0782)\end{array}$ & $\begin{array}{c}0.0715 \\
(0.0793)\end{array}$ \\
\hline $\begin{array}{l}\text { Border with } \\
\text { Wuerttemberg }\end{array}$ & $\begin{array}{c}1.201 \\
(1.040)\end{array}$ & $\begin{array}{l}-3.354 \\
(1.944)\end{array}$ & $\begin{array}{c}0.296 \\
(0.515)\end{array}$ & $\begin{array}{l}-0.327 \\
(0.466)\end{array}$ \\
\hline $\begin{array}{l}\text { Employment share } \\
\text { by industry }\end{array}$ & $\begin{array}{c}-0.00768 \\
(0.0200)\end{array}$ & $\begin{array}{l}-0.0390 \\
(0.0291)\end{array}$ & $\begin{array}{c}0.0255^{* * *} \\
(0.00828)\end{array}$ & $\begin{array}{l}-0.0164 \\
(0.0149)\end{array}$ \\
\hline Patents per year & $\begin{array}{c}0.0669 * * * \\
(0.0205)\end{array}$ & $\begin{array}{c}-0.107 * * * \\
(0.0213)\end{array}$ & $\begin{array}{c}0.0192 \\
(0.0164)\end{array}$ & $\begin{array}{c}-0.0880 * * * \\
(0.00531)\end{array}$ \\
\hline $\begin{array}{l}\text { Customs Union } \\
\text { (Zollverein) }\end{array}$ & $\begin{array}{c}-3.129 * * * \\
(0.917)\end{array}$ & $\begin{array}{l}-1.345 \\
(1.518)\end{array}$ & $\begin{array}{c}-2.156^{* * *} \\
(0.432)\end{array}$ & $\begin{array}{c}-1.167 * * * \\
(0.399)\end{array}$ \\
\hline Other German state & $\begin{array}{c}-2.622 * * \\
(1.096)\end{array}$ & $\begin{array}{l}-2.440 \\
(2.463)\end{array}$ & $\begin{array}{l}-0.517 \\
(1.762)\end{array}$ & \\
\hline Non-German state & $\begin{array}{c}-3.746 * * * \\
(1.265) \\
(0.0205)\end{array}$ & $\begin{array}{c}-4.275^{* *} \\
(1.986) \\
(0.0213)\end{array}$ & $\begin{array}{c}-3.041 * * * \\
(0.494) \\
(0.0164)\end{array}$ & $\begin{array}{c}-1.068 \\
(0.974) \\
(0.00531)\end{array}$ \\
\hline Constant & $\begin{array}{c}3.762 * * * \\
(0.352)\end{array}$ & $\begin{array}{c}14.92 * * * \\
(1.223)\end{array}$ & $\begin{array}{c}6.565 * * * \\
(0.761)\end{array}$ & $\begin{array}{c}11.43 * * * \\
(0.215)\end{array}$ \\
\hline Year fixed effects & Yes & Yes & Yes & Yes \\
\hline Observations & 98 & 56 & 275 & 281 \\
\hline$R^{2}$ & 0.372 & 0.573 & 0.367 & 0.159 \\
\hline
\end{tabular}

Notes: Robust standard errors in parentheses, clustered by sector. ${ }^{* *} p<0.01,{ }^{*} p<0.05,{ }^{*} p<0.1$. Sources: Authors' calculations, see the text.

intellectual property rights in the Netherlands in the following decades (until 1912). As a result, Dutch firms could imitate foreign innovations freely and without costs. A famous case in point is Gerard Philipps at Eindhoven, who started his production of incandescent electrical lamps in 1891 without paying any license fees to the original inventor, Thomas Alva Edison, who had been able to patent his basic invention in most other industrialized European countries. Similarly, Swiss chemical companies used the leeway provided by the absence of a Swiss domestic patent law by copying the innovative products of their German competitors. When international political pressure forced the Swiss government to introduce a patent law in 1888, it found an ingenious way to discriminate against German chemical firms. The Swiss patent law of 1888 only protected 
inventions that inventors could represent by mechanical models and, therefore, effectively excluded chemical inventions from patentability furthermore (Schiff 1971, p. 93).

The German entrepreneurs, who complained strongly about this Swiss legal trickery, could also have benefitted from inadequate national patent protection. Murmann (2003) argues that the absence of a national patent law before 1877 enabled German firms to imitate dyes invented in England or France. As in the Swiss case, many domestic firms freely entered the market and started a fierce price competition that only the most cost-effective companies survived. In contrast to this view, Donges and Selgert (2019a) consider the possibility that Baden, the western neighboring state of Wuerttemberg, fostered growth by treating domestic and foreign inventors equally in the mid-nineteenth century. This liberal patent practice might have facilitated the access to innovative foreign knowledge that domestic firms could get by disassembling imported machinery or scrutinizing patent descriptions.

In a broader perspective, discriminating against foreign inventors was just one of the many strategies aimed at acquiring superior foreign technology. Entrepreneurs from the European continent tried to imitate British technology by sending industrial spies (Harris 1998) who worked in innovative foreign companies for a while, smuggling out new machines or drawings of those machines, and hiring skilled foreign workers whom the government had forbidden to emigrate (Henderson 1972, pp. 4-9). Sidney Pollard (1981, p. 145 f.) concludes that these imitation strategies triggered industrialization throughout Europe. This view is shared by Bruland (1998, p. 163), who claims that technology transfer was integral to Scandinavian industrialization.

\section{CONCLUSION}

In the second half of the nineteenth century, Wuerttemberg was catching up to the more industrialized countries and became one of the most innovative regions throughout Europe. At the beginning of this development stands the reform of the state's patent law, which gave residents of the other member states of the German Customs Union the same formal rights as the local inventors. Scholars who like to stress the importance of institutions for economic growth might argue that the introduction of this particular set of inclusive institutions was an important precondition for the subsequent blossoming of innovative economic sectors, such as machine building or car manufacturing, in Wuerttemberg. Formal rules can be misleading, however. What often matters more is the 


\section{Wuerttemberg Patent Law in Administrative Practice 1097}

hidden agenda of the public administration that is responsible for enforcing these rules. We have shown in this article that the patent authority of Wuerttemberg, whose majority were local businessmen, discriminated strategically against foreign inventors from industrialized countries by charging comparatively high patent fees. This patent policy was driven by fiscal and protectionist motives. To generate revenues, the patent authority raised patent fees for inventions whose profitability was indicated by their assigned life span, the number of World's Fair exhibits of an ICO, and the status as patent of introduction. For protectionist reasons, patent fees were set higher when foreign patents affected industries with a high employment share in Wuerttemberg. As a probably desired side effect, this unequal treatment led foreigners to give up their patents prematurely.

If these discriminatory measures enabled local firms to imitate foreign technology faster than under truly fair conditions, the extractive use of formally inclusive institutions might have fostered economic development in Wuerttemberg. This tentative conclusion is in line with the argument by Boldrin and Levine (2008), who assume that the strict compliance to the international rules of law with respect to intellectual property rights will decelerate the speed of technological and economic progress in developing countries' domestic industry.

\section{REFERENCES}

Acemoglu, Daron, Davide Cantoni, Simon Johnson, and James A. Robinson. "The Consequence of Radical Reforms. The French Revolution." American Economic Review 101, no. 7 (2011): 3286-307.

Acemoglu, Daron, Simon Johnson, and James A. Robinson. "The Colonial Origins of Comparative Development: An Empirical Investigation." American Economic Review 91, no. 5 (2001): 1369-401.

Andersson, David E., and Fredrik Tell. "From Fighting Monopolies to Promoting Industry: Patent Laws and Innovation in Sweden 1819-1914." Jahrbuch für Wirtschaftsgeschichte 60, no. 1 (2019): 123-56.

Auriol, Emmanuelle, Sara Biancini, and Rodrigo Paillacar. "Universal Intellectual Property Rights: Too Much of a Good Thing?" International Journal of Industrial Organization 65, no. c (2019): 51-81.

Authority of Her Majesty's Commissioners. Official Catalogue Industrial Department International Exhibition 1862. London: Truscott, Son \& Simmons, 1862.

Boldrin, Michele, and David K. Levine. Against Intellectual Monopoly. Cambridge: Cambridge University Press, 2008.

Bruland, Kristine. "Skills, Learning and the International Diffusion of Technology: A Perspective on Scandinavian Industrialization." In Technological Revolutions in Europe, edited by Maxine Berg and Kristine Bruland, 161-87. Cheltenham: Edward Elgar, 1998. 
Clemens, Michael A., and Jeffrey G. Williamson. "Why Did the Tariff-Growth Correlation Change after 1950?" Journal of Economic Growth 9, no. 1 (2004): $5-46$.

DeLong, J. Bradford, and Andrei Shleifer. "Princes and Merchants: European City Growth before the Industrial Revolution." Journal of Law and Economics 2, no. 2 (1993): 671-702.

Deutscher Zollverein. Tabellen der Handwerker, der Fabriken, sowie der Handels- und Transportgewerbe im Zollverein. Nach der Aufnahme im Jahre 1861. Berlin 1864.

Dölemeyer, Barbara. "Erfinderprivilegien und frühe Patentgesetze." In Geschichte des deutschen Patentrechts, edited by Martin Otto and Diethelm Klippel, 13-36. Tübingen: Mohr Siebeck, 2015.

Donges, Alexander, Jean-Marie A. Meier, and Rui C. Silva. "The Impact of Institutions on Innovation." Unpublished Manuscript, 2018.

Donges, Alexander, and Felix Selgert. "Technology Transfer via Foreign Patents in Germany, 1843-1877.” Economic History Review 72, no. 1 (2019a): 182-208.

Donges, Alexander, and Felix Selgert. "Do Legal Differences Matter? A Comparison of German Patent Law Regimes before 1877." Jahrbuch für Wirtschaftsgeschichte 60, no. 1 (2019b): 57-92.

Donges, Alexander, and Felix Selgert. "The Consequences of Radical Patent-Regime Change.” Beiträge zur Jahrestagung des Vereins für Socialpolitik 2019: 30 Jahre Mauerfall - Demokratie und Marktwirtschaft - Session: Economic History 1, no. B24-V3, ZBW-Leibniz-Informationszentrum Wirtschaft, Kiel, 2019c.

Gehm, Matthias Hermann. "Das Württembergische Patentrecht im 19. Jahrhundert." Ph.D. diss., University of Saarland, 2001.

Geng, Difei, and Kamal Saggi. "Is there a Case for Non-Discrimination in the International Protection of Intellectual Property?" Journal of International Economics 97, no. 1 (2015): 14-28.

Grossman, Gene, and Edwin L.-C. Lai. "International Protection of Intellectual Property." American Economic Review 94, no. 5 (2004): 1635-53.

Harris, John R. Industrial Espionage and Technology Transfer. Britain and France in the Eighteenth Century. Aldershot: Ashgate Publishing, 1998.

Henderson, William O. Britain and Industrial Europe 1750-1870. 3rd ed. Leicester: Leicester University Press 1972.

Keller, Wolfgang, and Carol H. Shiue. "Endogeneous Formation of Free Trade Agreements: Evidence from the Zollverein's Impact on Market Integration." Journal of Economic History 74, no. 4 (2014): 1168-204.

Khan, B. Zorina. The Democratization of Invention: Patents and Copyrights in American Economic Development. Cambridge: Cambridge University Press, 2005.

Khan, B. Zorina. "Designing Women: Consumer Goods Innovations in Britain, France and the United States, 1750-1900.” NBER Working Paper No. 23086, Cambridge, MA, 2017.

Kollmer-von-Oheimb-Loup, Gert. "Ferdinand von Steinbeis - Mythos und Wirklichkeit. Neue Überlegungen zur Geschichte der Gewerbeförderung in Württemberg." Jahrbuch für Wirtschaftsgeschichte 39, no. 1 (1998): 201-24.

Kollmer-von-Oheimb-Loup, Gert. Schwäbische Tüftler und Erfinder - Abschied vom Mythos? Ostfildern: Thorbecke, 2016.

Kotabe, Masaaki. "A Comparative Study of US and Japanese Patent Systems." Journal of International Business Studies 23, no. 1 (1992): 147-68. 


\section{Wuerttemberg Patent Law in Administrative Practice 1099}

Lehmann-Hasemeyer, Sibylle, and Jochen Streb. "The Berlin Stock Exchange in Imperial Germany - A Market for New Technology?" American Economic Review 106, no. 11 (2016): 3558-76.

"Discrimination against Foreigners." Ann Arbor, MI: Inter-university Consortium for Political and Social Research [distributor], 2020-03-06. https:// doi.org/10.3886/E118081V1.

Lerner, Josh. "150 Years of Patent Protection.” NBER Working Paper No. 7478, Cambridge, MA, 2000.

Mai, Joseph, and Andrey Stoyanow. "Home Country Bias in the Legal System: Empirical Evidence from the Intellectual Property Rights Protection in Canada." York University Department of Economics Working Papers 2014_2, Toronto, Canada, 2014.

Maskus, Keith E. "Incorporating a Globalized Intellectual Property Rights Regime into an Economic Development Strategy." In Intellectual Property, Growth and Trade, edited by Keith E. Maskus, 497-524. Amsterdam: Emerald, 2008.

Mauersberg, Hans. Finanzstrukturen deutscher Bundesstaaten zwischen 1820 und 1944. St. Katharinen: Scripta Mercaturae, 1988.

Moser, Petra. "How Do Patent Laws Influence Innovation? Evidence from $19^{\text {th }}$-Century World Fairs." American Economic Review 95, no. 4 (2005): 1214-36.

Moser, Petra. "Innovation without Patents: Evidence from World's Fairs." Journal of Law and Economics 55, no. 1 (2012): 43-74.

Münzenmayer, Hans Peter. Patente in Württemberg 1818-1877. Wirtschaftsarchiv Baden-Württemberg 3060/122, no date.

Murmann, Johann Peter. Knowledge and Competitive Advantage, Cambridge: Cambridge University Press, 2003.

Nicholas, Tom. “Cheaper Patents." Research Policy 40, no. 2 (2011): 325-39.

North, Douglass C. Institutions, Institutional Change and Economic Performance. Cambridge: Cambridge University Press, 1990.

North, Douglass C., and Barry R. Weingast. "Constitutions and Commitment: The Evolution of Institutions Governing Public Choice in Seventeenth-Century England." Journal of Economic History 49, no. 4 (1989): 803-32.

Nuvolari, Alessandro, and Michelangelo Vasta. "Independent Invention in Italy during the Liberal Age, 1861-1913." Economic History Review 68, no. 3 (2015): 858-86.

O'Rourke, Kevin, and Jeffrey G. Williamson. Globalization and History. The Evolution of a Nineteenth-Century Atlantic Economy. Cambridge, MA: MIT Press, 1999.

Paulinyi, Akos. "Die Rolle der preußischen Gewerbeförderung beim Techniktransfer im Maschinenbau." In Wissenschafts- und Technologietransfer zwischen Industrieller und Wissenschaftlich-technischer Revolution, edited by Klaus Peter Meinicke and Klaus Krug, 68-82. Stuttgart: GNT Verlag, 1992.

Peukert, Alexander. "Intellectual Property and Development - Narratives and their Empirical Validity." Journal of World Intellectual Property 20, nos. 1-2 (2017): 2-23.

Ploeckl, Florian. "The Zollverein and the Sequence of a Customs Union." Australian Economic History Review 55, no. 3 (2015): 277-300.

Pollard, Sidney. Peaceful Conquest. The Industrialization of Europe 1760-1970. Oxford: Oxford University Press, 1981.

Richter, Ralf, and Jochen Streb. "Catching-Up and Falling Behind: Knowledge Spillover from American to German Machine Tool Makers." Journal of Economic History 71, no. 4 (2011): 1006-31. 
Sáiz, J. Patricio, and David Pretel D. "Why Did Multinationals Patent in Spain? Several Historical Inquiries." In Organizing Global Technology Flows: Institutions, Actors, and Processes, edited by Pierre-Yves Donzé and Shigehiro Nishimura, 39-59. New York: Routledge/Oxford, 2013.

Schankerman, Mark, and Ariel Pakes. "Estimates of the Value of Patent Rights in European Countries during the Post-1950 Period." Economic Journal 96, no. 4 (1986): 1052-76.

Schiff, Eric. Industrialization without National Patents. Princeton: Princeton University Press, 1971.

Seckelmann, Margrit. Industrialisierung, Internationalisierung und Patentrecht im Deutschen Reich 1871-1914. Frankfurt: Klostermann, 2006.

Selgert, Felix. Baden and the Modern State. The Implementation of Administration and Legal Reforms in the German State of Baden during the 19th Century. Berlin: de Gruyter, 2018.

Statistisches Landesamt für Baden-Württemberg. Jahrbücher für Statistik und Landeskunde von Baden-Württemberg. Stuttgart: Kohlhammer, 1974.

Streb, Jochen. Trumpf: The Story of a Family Business. Munich: Hanser, 2019.

Streb, Jochen, Jörg Baten, and Shuxi Yin. "Technological and Geographical Knowledge Spillover in the German Empire 1877-1918." Economic History Review 59, no. 2 (2006): 347-73.

Timmer, Ashley S., and Jeffrey G. Williamson. "Immigration Policy Prior to the 1930s: Labor Markets, Policy Interactions, and Globalization Backlash.” Population and Development Review 24, no. 4 (1998): 739-71.

Vischer, Ludwig. Die industrielle Entwicklung in Württemberg und das Wirken seiner Centralstelle für Gewerbe und Handel in ihren ersten 25 Jahren. Stuttgart: Verlag Carl Grüninger, 1875.

Webster, Elizabeth, Paul H. Jensen, and Alfons Palangkaraya. "Patent Examination Outcomes and the National Treatment Principle." RAND Journal of Economics 45, no. 2 (2014): 449-69.

Wolf, Nikolaus. "Was Germany Ever United? Evidence from Intra- and International Trade, 1880-1933.” Journal of Economic History 69, no. 3 (2009): 846-81. 